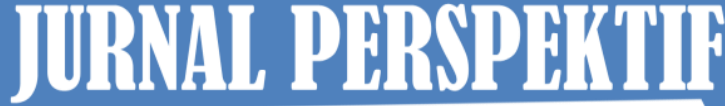

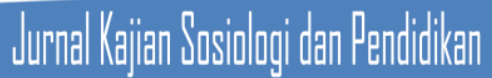

Jurnal Perspektif: Jurnal Kajian Sosiologi dan Pendidikan

Vol. 2 No. 3 Tahun 2019

http://perspektif.ppj.unp.ac.id

Email: perspektif@ppj.unp.ac.id

ISSN: 2622-1748 (Online), 2684-902X (Print)

DOI: http://dx.doi.org/10.24036/perspektif.v2i3.77

\title{
Analisis SWOT Pelaksanaan Operasi SAR Kantor Pencarian dan Pertolongan Padang
}

\author{
Anisa Khairoza', Zikri Alhadi ${ }^{2}$ \\ 1,2Universitas Negeri Padang \\ Email: anisakhairoza@gmail.com, ianunpzikri@yahoo.co.id
}

\begin{abstract}
Abstrak
Penelitian ini bertujuan untuk menganalisis kekuatan, kelemahan, peluang dan ancaman yang dihadapi Kantor Pencarian dan Pertolongan Padang dalam melakukan Operasi SAR. Penelitian ini menggunakan metode penelitian kualitatif deskriptif. Hasil dari penelitian ini menunjukkan bahwa yang menjadi kekuatan Kantor Pencarian dan Pertolongan Padang dalam melakukan Operasi SAR adalah memiliki landasan hukum yang jelas dan sumber daya manusia yang berkualitas. Adapun kelemahan yang dihadapi adalah masih terbatasnya sarana dan prasarana disebabkan keterbatasan anggaran dana dari Pemerintah. Kemudian yang menjadi peluang adalah dengan adanya undangundang nomor 29 tahun 2014 telah memberikan peluang untuk melakukan kerjasama dengan instansi yang memiliki potensi dalam melakukan Operasi SAR. Selanjutnya ancaman yang dihadapi adalah cuaca ekstrim dan keadaan lokasi kejadian. Adapun upaya yang dilakukan untuk mengatasi hambatanhambatan yang dihadapi dalam melakukan Operasi SAR adalah melakukan kerjasama dengan instansi terkait sehingga dapat menutupi kelemahan-kelemahan yang ada.
\end{abstract}

Kata Kunci : Analisis SWOT, BASARNAS, Operasi SAR, Penanggulangan Bencana

\section{Abstract}

This study aims to analyze the strengths, weaknesses, opportunities and threats faced by the Padang Search and Rescue Office in conducting SAR Operations. This study uses descriptive qualitative research methods. The results of this study indicate that the strength of the Padang Search and Rescue Office in conducting SAR operations is to have a clear legal basis and quality resources. The weaknesses faced were limited facilities and infrastructure due to limited budgetary funds from the Government. Then the opportunity is that the existence of law number 29 of 2014 has provided an opportunity to collaborate with relevant agencies in conducting SAR Operations. Furthermore, the threat faced in conducting SAR Operations is extreme weather and the situation of the scene. As for the efforts made to overcome the obstacles faced in conducting SAR Operations are to collaborate with relevant agencies so that they can cover up existing weaknesses.

Keywords : SWOT Analysis, BASARNAS, SAR Operation, Disaster Management

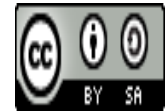




\section{Pendahuluan}

Dengan masuknya Indonesia sebagai anggota ICAO (International Civil Aviation Organization) dan IMO (International Maritime Organization) mewajibkan bahwa suatu negara harus memiliki organisasi pencarian dan pertolongan karena apabila suatu negara tidak memiliki organisasi pencarian dan pertolongan maka dianggap sebagai Black Area artinya bahwa negara tersebut tidak dapat memberikan rasa aman dalam melakukan penerbangan dan pelayaran. Untuk menindaklanjuti hal tersebut, Indonesia telah membentuk Badan Nasional Pencarian dan Pertolongan atau BASARNAS. Salah satu tugas dari Badan Nasional Pencarian dan Pertolongan adalah melakukan tanggap darurat bencana yaitu mencari dan menolong korban bencana dan musibah. Berdasarkan UU No. 29 Tahun 2014 tentang Pencarian dan Pertolongan, pencarian dan pertolongan adalah suatu rangkaian kegiatan mencari, menolong, menyelamatkan dan mengevakuasi korban. Korban yang dimaksudkan disini adalah orang yang mengalami penderitaan akibat bencana atau kondisi membahayakan jiwa manusia seperti musibah penerbangan dan pelayaran, orang hanyut di sungai, dan musibah lainnya.

Manajemen bencana menurut Sadisun (dalam Alhadi, 2014:8(1),37) merupakan suatu rangkaian kegiatan yang dinamis dan terpadu yang dilaksanakan dalam tiga tahapan yaitu pra bencana, tanggap darurat bencana maupun pasca bencana. Dalam kebencanaan, Badan Nasional Pencarian dan Pertolongan memiliki peranan pada tahapan tanggap darurat bencana yaitu melakukan Operasi SAR (pencarian dan pertolongan). Berdasarkan UU No. 24 Tahun 2007 tentang Penanggulangan Bencana, tanggap darurat bencana adalah kegiatan penyelamatan dan evakuasi korban yang dilakukan sesaat terjadinya bencana dalam rangka meminimalisir dampak buruk yang mungkin terjadi akibat dari bencana tersebut seperti bertambahnya korban.

Sumatera Barat merupakan wilayah yang memiliki kerawanan terjadinya bencana dan musibah yang cukup tinggi. Hal ini dapat dilihat pada kejadian bencana dan musibah yang terjadi di Provinsi Sumatera Barat pada tabel berikut ini:

Tabel 1. Kejadian Bencana dan musibah di Provinsi Sumatera Barat Tahun 2016-2018

\begin{tabular}{clcccccc}
\hline \multirow{2}{*}{ No } & Bulan & 2016 & $\begin{array}{c}\text { Bencana } \\
2017\end{array}$ & 2018 & 2016 & 2017 & 2018 \\
\hline 1 & Januari & 1 & 2 & - & 5 & 15 & 2 \\
\hline 2 & Februari & 3 & - & - & 8 & 9 & 8 \\
\hline 3 & Maret & 2 & 2 & - & 6 & 5 & 3 \\
\hline 4 & April & 1 & 1 & - & 5 & 1 & 3 \\
\hline 5 & Mei & 1 & 1 & - & 7 & 5 & 8 \\
\hline 6 & Juni & 2 & - & - & 4 & 3 & 9 \\
\hline 7 & Juli & - & - & 1 & 1 & 5 & 5 \\
\hline 8 & Agustus & 1 & - & - & 5 & 7 & 4 \\
\hline 9 & September & - & 1 & 1 & 4 & 6 & 6 \\
\hline 10 & Oktober & - & - & 3 & 3 & 3 & 7 \\
\hline 11 & November & 2 & 1 & 5 & 7 & 5 & 14 \\
\hline 12 & Desember & 3 & 1 & 2 & 12 & 3 & 6 \\
\hline Jumlah & & $\mathbf{1 6}$ & $\mathbf{9}$ & $\mathbf{1 2}$ & $\mathbf{6 7}$ & $\mathbf{6 7}$ & $\mathbf{7 5}$ \\
\hline
\end{tabular}

Sumber: Kantor Pencarian dan Pertolongan Padang 
Dari tabel diatas dapat diketahui bahwa setiap tahunnya selalu terjadi baik bencana maupun musibah di Provinsi Sumatera Barat. Menanggapi hal tersebut maka dibentuklah unit pelaksana teknis yang merupakan perpanjangan tangan dari Badan Nasional Pencarian dan Pertolongan yaitu Kantor Pencarian dan Pertolongan. Saat ini, Provinsi Sumatera Barat memiliki dua Kantor Pencarian dan Pertolongan yaitu berlokasi di Kota Padang dan Kabupaten Kepulauan Mentawai. Kantor Pencarian dan Pertolongan Padang memiliki wilayah kerja yang cukup luas yaitu mencakup seluruh kota maupun kabupaten yang ada di Provinsi Sumatera Barat.

Dalam melakukan Operasi SAR, Kantor Pencarian dan Pertolongan Padang menghadapi beberapa faktor yang dibagi menjadi faktor eksternal dan internal. Faktor internal terdiri dari kekuatan dan kelemahan. Yang dimaksud kekuatan menurut Salusu (2015:177) adalah situasi internal suatu organisasi yang memungkinkan organisasi tersebut memiliki keuntungan dalam mencapai sasarannya. Yang menjadi kekuatan Kantor Pencarian dan Pertolongan Padang dalam melakukan Operasi $S A R$ adalah memiliki landasan hukum yang jelas dan sumber daya manusia yang berkualitas. Kelemahan menurut Hadi (2013:14(1),145) adalah keterbatasan sumber daya yang ada sehingga dapat menghambat tercapainya tujuan organisasi. Kelemahan yang dihadapi Kantor Pencarian dan Pertolongan Padang adalah masih kurangnya ketersediaan sarana dan prasarana yang dimiliki. Faktor eksternal dalam SWOT meliputi peluang dan ancaman. Menurut Sutrisno (2011:3(2),47) peluang adalah suatu kondisi yang dapat menguntungkan suatu oganisasi dalam menjalankan tugasnya. Adapun yang menjadi peluang Kantor Pencarian dan Pertolongan Padang dalam melakukan Operasi $S A R$ adalah dengan adanya UU yang mengatur pelaksanaan pencarian dan pertolongan telah memberikan peluang kepada Kantor Pencarian dan Pertolongan Padang untuk melakukan kerjasama dengan instansi yang memiliki potensi dalam melakukan pencarian dan pertolongan. Ancaman menurut Nurhayati (2009:1(5),150) merupakan suatu kondisi yang dapat menghambat suatu organisasi dalam melaksanakan suatu kegiatan. Kendala atau hambatan yang dihadapi Kantor Pencarian dan Pertolongan Padang dalam melakukan pencarian dan pertolongan adalah cuaca ekstrim atau lokasi kejadian.

Artikel ini bertujuan untuk menganalisis kekuatan, kelemahan, peluang dan ancaman yang dihadapi Kantor Pencarian dan Pertolongan Padang dalam melakukan Operasi SAR serta membahas upaya-upaya yang dilakukan Kantor Pencarian dan Pertolongan Padang untuk mengatasi hambatan yang dihadapi dalam melakukan Operasi SAR.

\section{Metode Penelitian}

Dalam penelitian ini, metode penelitian yang peneliti gunakan adalah penelitian kualitatif dengan metode deskriptif. Menurut Moleong (2013:6) metode kualitatif merupakan penelitian yang bertujuan untuk memahami kejadian-kejadian yang dialami oleh subjek penelitian dan digambarkan dalam bentuk kata-kata dan bahasa. Penelitian ini dilakukan di Kantor Pencarian dan Pertolongan Padang dan beberapa BPBD Kota/Kabupaten di Provinsi Sumatera Barat. Teknik pengumpulan data dilakukan dengan cara wawancara dan studi dokumentasi. Analisis data dilakukan melalui reduksi data, penyajian data dan menarik kesimpulan. 


\section{Hasil}

\section{Analisis SWOT}

Dalam penelitian ini, analisis SWOT digunakan untuk mengidentifikasi empat faktor utama yang mempengaruhi kegiatan Kantor Pencarian dan Pertolongan Padang dalam melakukan tanggap darurat bencana atau Operasi SAR. Adapun empat faktor utama tersebut meliputi:

\section{Kekuatan (Strengths)}

Kekuatan adalah faktor internal yang merupakan kemampuan suatu organisasi yang berasal dari internal organisasi dan memudahkan organisasi tersebut dalam mencapai sasaran kegiatannya. Dalam penelitian ini yang menjadi kekuatan Kantor Pencarian dan Pertolongan Padang dalam melakukan tanggap darurat bencana adalah sebagai berikut:

a. Adanya landasan hukum yang jelas

Berdasarkan penelitian yang telah dilakukan menunjukkan bahwa yang menjadi kekuatan Kantor Pencarian dan Pertolongan Padang dalam melakukan tanggap darurat bencana dalam hal ini adalah operasi pencarian dan pertolongan ( $S A R$ ) yaitu memiliki landasan hukum yang jelas yaitu UU No. 29 Tahun 2014. Dengan adanya UU tersebut telah memudahkan Kantor Pencarian dan Pertolongan Padang dalam melakukan operasi SAR karena prosedur pelaksanaannya telah diatur di dalamnya. Adapun SOP pelaksanaan operasi $S A R$ terdiri dari siaga dan operasi pencarian dan pertolongan. Kantor Pencarian dan Pertolongan Padang selalu melakukan siaga selama 24 jam untuk kesigapan. Dalam melakukan siaga terdapat tiga tim yang mana satu tim terdiri dari 8 orang. Tim tersebut melakukan siaga secara bergantian sesuai dengan pembagian waktu. Sedangkan pelaksanaan operasi SAR dilaksanakan selama 7 (tujuh) hari. Namun, jangka waktu pelaksanaan operasi $S A R$ dapat diperpanjang atau dibuka kembali apabila ada tanda-tanda ditemukannya korban. tidak hanya memiliki landasan hukum yang jelas dalam pelaksanaan operasi $S A R$, namun struktur organisasi Kantor Pencarian dan Pertolongan Padang juga telah diatur oleh Peraturan Kepala Badan sehingga memiliki struktur organisasi yang tidak ribet karena tugas dan tanggungjawab sudah jelas diatur dalam peraturan tersebut.

b. Memiliki sumber daya manusia yang berkualitas

Kekuatan lain yang dimiliki Kantor Pencarian dan Pertolongan Padang dalam melakukan tanggap darurat bencana adalah memiliki pegawai yang berkualitas. Sumber daya manusia Kantor Pencarian dan Pertolongan Padang terutama personil lapangan memiliki kemampuan dan keahlian yang cukup baik karena diberikan pendidikan dan pelatihan yang berjenjang dan bertahap serta latihan yang berkelanjutan kepada pegawainya sehingga dapat bekerja secara profesional. Untuk meningkatkan kemampuan pegawai Rescuer Kantor Pencarian dan Pertolongan Padang dalam melakukan Operasi SAR maka diadakan latihan dan pelatihan. Latihan bertujuan untuk melatih kemampuan-kemampuan tim internal. Dari internal diberikan pelatihan fisik yang dilakukan tiga kali dalam seminggu dan dari eksternal diadakan pelatihan untuk meningkatkan pengetahuan mereka yang terdiri dari tiga bentuk pelatihan yaitu water rescue, jungle rescue dan air rescue tecnic. Pelatihan yang dilakukan bertujuan untuk meningkatkan pengetahuan personil lapangan terhadap alat baru karena semakin berkembangnya zaman maka alat juga semakin canggih sehingga mereka juga akan disekolahkan untuk mempelajari alat tersebut. Pelatihan juga diberikan untuk potensi-potensi yang ada. Kemudian ada lagi namanya uji kompetensi yang dilakukan dua kali setahun. Uji kompetensi dilakukan dengan mendatangkan instruktur dari pusat untuk menguji kemampuan-kemampuan tim kita itu dua kali setahun. 


\section{Kelemahan (Weaknesses)}

Kelemahan adalah faktor internal yang merupakan kekurangan yang dimiliki oleh suatu organisasi. Kelemahan disini diartikan sebagai kekurangan yang dialami Kantor Pencarian dan Pertolongan Padang dalam melakukan tanggap darurat bencana. Adapun yang menjadi kelemahan Kantor Pencarian dan Pertolongan Padang dalam melakukan tanggap darurat bencana yaitu sebagai berikut:

a. Masih kurangnya ketersediaan sarana dan prasarana

Sarana dan prasarana mempengaruhi keberhasilan dari pelaksanaan tanggap darurat bencana, apabila sarana dan prasarana yang dimiliki terbatas tentunya akan menghambat Kantor Pencarian dan Pertolongan Padang dalam melakukan operasi SAR. Untuk mengetahui jumlah sarana dan prasarana yang dimiliki Kantor Pencarian dan Pertolongan Padang dapat dilihat pada tabel berikut ini:

\section{Tabel 2. Sarana dan Prasarana Kantor Pencarian dan Pertolongan Padang}

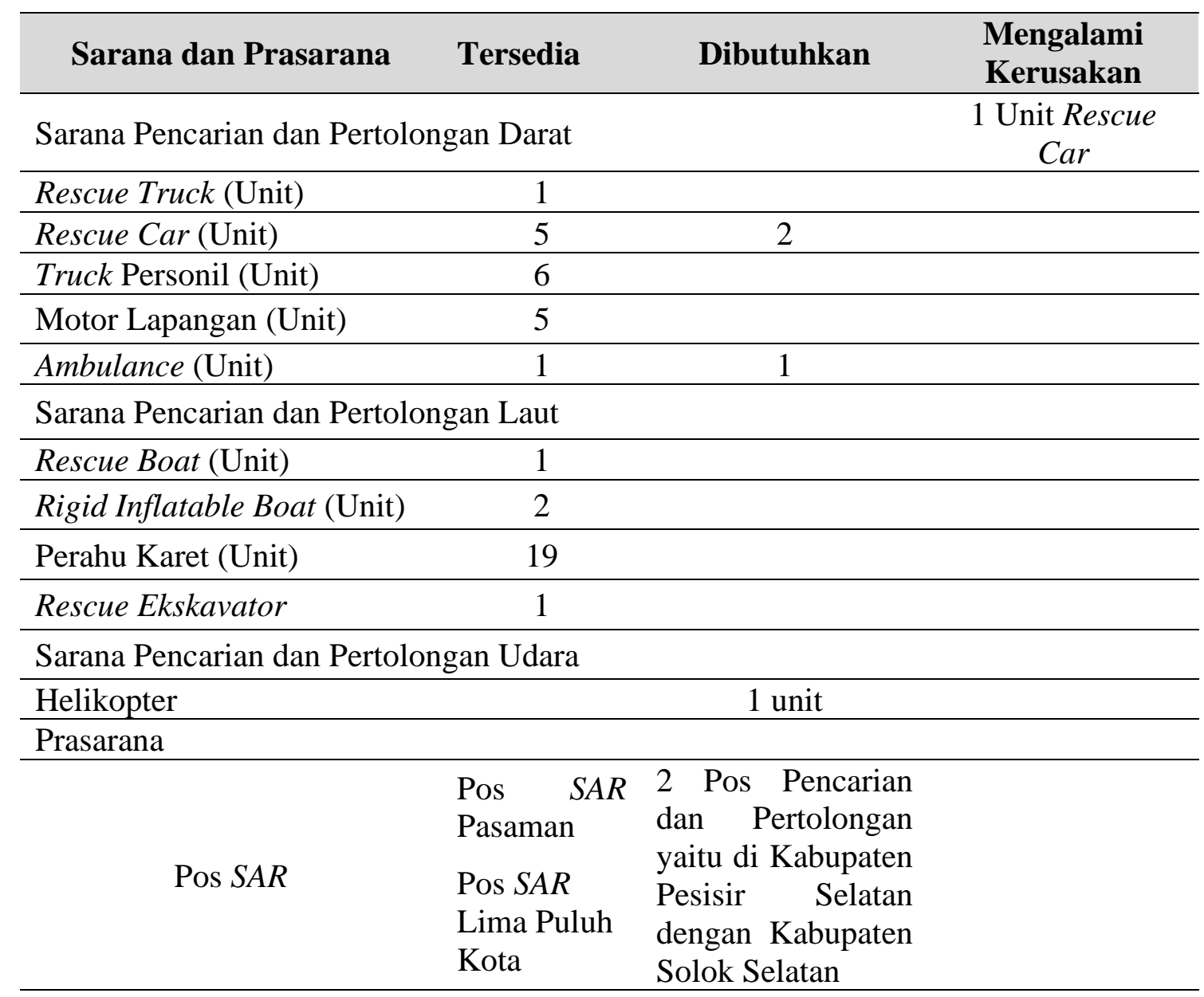

Sumber: Kantor Pencarian dan Pertolongan Padang (Data Olahan Penulis,2019)

Dari tabel diatas dapat diketahui bahwa sarana dan prasarana yang dimiliki Kantor Pencarian dan Pertolongan Padang belum sesuai dengan yang dibutuhkan dalam melakukan operasi $S A R$ karena ada beberapa sarana yang masih mengalami kekurangan dan masih membutuhkan tambahan. Sarana dan prasarana yang dimiliki Kantor Pencarian dan Pertolongan Padang masih mengalami kekurangan seperti sarana udara yang belum ada 
kemudian untuk sarana darat masih perlu penambahan 2 unit rescue car dan satu unit ambulance dan Pos Pencarian dan Pertolongan yang dimiliki masih belum sesuai dengan kebutuhan untuk mengcover luas wilayah kerja. Dengan kurangnya sarana dan prasarana yang dimiliki tentunya akan mengakibatkan tidak efektifnya pelaksanaan operasi $S A R$ terlebih Pos Pencarian dan Pertolongan yang belum sesuai dengan kebutuhan yaitu masih perlu penambahan untuk wilayah Kabupaten Pesisir Selatan dan Kabupaten Solok Selatan. Berdasarkan Peraturan Kepala Badan Nasional Pencarian dan Pertolongan No. 16 Tahun 2017 tentang Organisasi dan Tata Kerja Kantor Pencarian dan Pertolongan pasal 12, tujuan dibentuknya Pos Pencarian dan Pertolongan adalah untuk mempercepat pelayanan tugas pencarian dan pertolongan sehingga apabila daerah yang memiliki potensi bencana yang tinggi tidak terdapat Pos disana tentunya akan menyebabkan keterlambatan dalam melaksanakan tugas karena jarak tempuh yang dihadapi Kantor Pencarian dan Pertolongan Padang untuk mencapai daerah yang mengalami bencana atau musibah.

b. Terbatasnya anggaran untuk memenuhi kekurangan sarana dan prasarana

Masalah utama yang dialami oleh Kantor Pencarian dan Pertolongan Padang dalam melakukan Operasi $S A R$ adalah masih terbatasnya anggaran dana yang dimiliki. Anggaran yang tidak terealisasi sepenuhnya dari yang dibutuhkan Badan Nasional Pencarian dan Pertolongan untuk memenuhi kebutuhan akan sarana dan prasarana juga ikut berdampak terhadap anggaran dana yang diberikan kepada Kantor Pencarian dan Pertolongan Padang. Hal ini ditunjukkan dengan anggaran yang dibutuhkan yaitu sebesar Rp 4.975.812.000 namun yang terealisasi hanya sebesar Rp 4.961.929.950 sehingga mengakibatkan sarana dan prasarana yang dimiliki Kantor Pencarian dan Pertolongan Padang juga masih belum terpenuhi secara optimal.

\section{Peluang (Opportunity)}

Peluang merupakan suatu kesempatan yang tersedia dan dapat menjadi pendorong proses kinerja suatu organisasi. Berdasarkan hasil penelitian menunjukkan bahwa yang menjadi peluang Kantor Pencarian dan Pertolongan Padang dalam melakukan operasi SAR adalah dengan adanya kekuatan hukum yaitu UU No. 29 Tahun 2014 maka Kantor Pencarian dan Pertolongan Padang berpeluang untuk melakukan kerjasama dengan instansi lain yang memiliki potensi dalam melakukan pencarian dan pertolongan salah satunya yaitu Badan Penanggulangan Bencana Daerah karena pada pasal 38 ayat 1 UU No. 29 Tahun 2014 berbunyi bahwa setiap instansi yang memiliki potensi pencarian dan pertolongan yang ada wajib hukumnya untuk membantu Kantor Pencarian dan Pertolongan Padang dalam melakukan pencarian dan pertolongan. Tidak hanya itu, dengan adanya kesamaan tujuan dari instansi masing-masing yaitu dalam rangka melakukan penyelamatan, pencarian dan pertolongan dalam masalah kebencanaan juga menjadi alasan timbulnya kerjasama ini.

\section{Ancaman (Threats)}

Ancaman merupakan faktor-faktor yang berasal dari lingkungan luar organisasi yang dapat menghambat organisasi bersangkutan dalam menjalankan tugasnya. Ancaman disini dapat diartikan sebagai kendala yang dihadapi Kantor Pencarian dan Pertolongan Padang dalam melakukan tanggap darurat bencana karena adanya gangguan dari luar organisasi dalam pelaksanaannya. Berdasarkan penelitian yang telah dilakukan, yang menjadi ancaman Kantor Pencarian dan Pertolongan Padang dalam melakukan tanggap darurat bencana adalah permintaan dari keluarga korban yang ingin keluarganya cepat ditemukan namun Kantor Pencarian dan Pertolongan Padang harus bekerja sesuai dengan SOP. Kemudian cuaca dan 
keadaan lokasi yang tidak mendukung seperti gelombang laut yang tinggi atau aliran sungai yang deras sehingga pelaksanaan operasi $S A R$ menjadi terhambat.

\section{Upaya yang dilakukan Kantor Pencarian dan Pertolongan Padang dalam mengatasi kendala-kendala yang dihadapi dalam melakukan Operasi $S A R$}

Upaya adalah langkah-langkah yang dilakukan untuk meningkatkan kinerja suatu organisasi. Dalam melaksanakan operasi pencarian dan pertolongan, Kantor Pencarian dan Pertolongan Padang tentunya tidak dapat terhindar dari kendala-kendala yang dapat menyebabkan pelaksanaan operasi $S A R$ tidak berjalan dengan baik, untuk itu sangat perlu dilakukan upaya-upaya untuk meningkatkan kinerja Kantor Pencarian dan Pertolongan Padang dalam melakukan operasi pencarian dan pertolongan.

Dalam melakukan tanggap darurat bencana yaitu melakukan Operasi SAR, Kantor Pencarian dan Pertolongan Padang masih terkendala dengan keterbatasan sarana dan prasarana. Untuk mengatasi kekurangan sarana prasarana yang dimiliki ketika terjun ke lapangan, Kantor Pencarian dan Pertolongan Padang bekerjasama dengan instansi terkait yang memiliki potensi dalam melakukan pencarian dan pertolongan dalam hal ini yaitu Badan Penanggulangan Bencana Daerah. Kerjasama yang dilakukan tidak hanya untuk menutupi kekurangan yang dialami Kantor Pencarian dan Pertolongan Padang, namun juga untuk menutupi kekurangan dari BPBD dalam melakukan tanggap darurat bencana sehingga dengan adanya kerjasama yang dilakukan baik kekurangan akan sumber daya manusia maupun sarana prasarana dapat teratasi.

\section{Pembahasan}

Berdasarkan hasil penelitian yang telah dijelaskan sebelumnya, peneliti akan menjelaskan dan menganalisis data yang diperoleh melalui literatur mengenai analisis SWOT pelaksanaan Operasi SAR Kantor Pencarian dan Pertolongan Padang.

\section{Kekuatan (Strengths)}

Kekuatan menurut Salusu (2015:177) merupakan suatu situasi yang memberikan kemungkinan kepada suatu organisasi untuk mendapatkan keuntungan dalam mencapai tujuan atau sasaran yang diinginkan. Adapun beberapa hal yang menjadi kekuatan sehingga mendorong kinerja Kantor Pencarian dan Pertolongan Padang menjadi lebih baik dalam melakukan operasi pencarian dan pertolongan adalah memiliki landasan hukum yang jelas dan memiliki sumber daya manusia yang berkualitas. Dengan adanya hukum yang jelas untuk mengatur pelaksanaan Operasi SAR telah memudahkan Kantor Pencarian dan Pertolongan Padang dalam melaksanakan tugasnya tersebut karena semua prosedur yang ada telah diatur didalamnya mulai dari awal pelaksanaan operasi pencarian dan pertolongan hingga ketentuan-ketentuan atau sebab-sebab operasi $S A R$ dapat dihentikan pelaksanaanya. Selain itu, sumber daya manusia yang berkualitas juga menjadi kekuatan lainnya dalam pelaksanaan Operasi $S A R$. Dengan adanya pelatihan-pelatihan yang diberikan secara bertahap dan berkelanjutan kepada personil lapangan telah menjadikan personil tersebut memiliki pengetahuan dan keahlian yang cukup baik sehingga dapat bekerja secara profesional.

\section{Kelemahan (Weaknesses)}

Menurut Barry dalam Salusu (2015) kelemahan-kelemahan yang pada umumnya dirasakan oleh suatu organisasi antara lain yaitu lokasi yang jauh dari jangkauan fasilitas umum, keuangan yang tidak memadai, serta masih kurangnya ketersediaan sarana dan prasarana. Hal ini pula yang dirasakan oleh Kantor Pencarian dan Pertolongan Padang dalam 
menjalankan tuganya. Sarana dan prasarana yang dimiliki Kantor Pencarian dan Pertolongan Padang belum sesuai dengan yang dibutuhkan dalam melakukan Operasi $S A R$ karena ada beberapa sarana yang masih mengalami kekurangan dan masih membutuhkan tambahan seperti memerlukan tambahan untuk rescue car dan ambulance. Hal ini terjadi juga tidak lain karena masih terbatasnya anggaran dana yang diberikan oleh Pemerintah untuk memenuhi kebutuhan akan sarana dan prasarana tersebut.

\section{Peluang (Opportunity)}

Menurut Barry dalam Sulusu (2015) peluang dapat diartikan sebagai suatu kesempatan yang dapat dimanfaatkan untuk mendorong proses kegiatan yang dilaksanakan oleh suatu organisasi. Adapun yang menjadi peluang Kantor Pencarian dan Pertolongan Padang dalam melakukan Operasi $S A R$ adalah dengan adanya kekuatan hukum yaitu UU No. 29 Tahun 2014 dan memiliki kesamaan tujuan dengan instansi terkait telah memberikan kesempatan kepada Kantor Pencarian dan Pertolongan Padang untuk melakukan kerjasama dengan instansi lain yang memiliki potensi dalam melakukan pencarian dan pertolongan sehingga dengan adanya kerjasama ini telah membantu Kantor Pencarian dan Pertolongan Padang untuk bekerja lebih efektif.

\section{Ancaman (Threats)}

Menurut Barry dalam Salusu (2015) bahwa ancaman adalah suatu kondisi atau permasalahan yang dapat menimbulkan kesulitan, kendala yang cukup serius bagi suatu instansi tertentu. Adapun kesulitan-kesulitan yang dihadapi Kantor Pencarian dan Pertolongan Padang ketika bekerja di lapangan adalah cuaca dan keadaan lokasi yang tidak mendukung seperti gelombang air laut yang tinggi ketika melakukan proses pencarian korban yang tenggelam di laut sehingga keadaan ini dapat menghambat Kantor Pencarian dan Pertolongan Padang dalam melaksanakan tugasnya. Hal ini juga berdampak kepada hasil dari proses pencarian seperti korban menjadi lama ditemukan dan tidak sesuai dengan keinginan dari keluarga korban yang ingin keluarganya cepat ditemukan.

\section{Kesimpulan}

Dari beberapa penjelasan diatas dapat ditarik kesimpulan bahwa yang menjadi kekuatan Kantor Pencarian dan Pertolongan Padang dalam melakukan tanggap darurat bencana atau operasi pencarian dan pertolongan adalah adanya landasan hukum yang jelas yaitu UU No. 29 Tahun 2014 telah memudahkan Kantor Pencarian dan pertolongan Padang dalam melakukan tanggap darurat bencana dan memiliki pegawai yang berkualitas sehingga dapat melaksanakan tanggap darurat bencana secara profesional. Dengan kekuatan yang dimiliki diharapkan Kantor Pencarian dan Pertolongan Padang mampu untuk melaksanakan tanggap darurat bencana lebih efektif dan efesien. Kemudian kelemahan yang dihadapi Kantor Pencarian dan Pertolongan Padang adalah masih kurangnya ketersediaan sarana dan prasarana dalam melakukan Operasi $S A R$ dan masih terbatasnya anggaran dana untuk memenuhi kebutuhan akan sarana dan prasarana tersebut. Dengan kelemahan yang dimiliki, Kantor Pencarian dan Pertolongan Padang diharapkan dapat memperbaiki karena kelemahan suatu organisasi tidak boleh dibiarkan sepanjang perbaikan dapat dilakukan. Selanjutnya peluangnya adalah dengan adanya kekuatan hukum memberikan peluang kepada Kantor Pencarian dan Pertolongan Padang untuk melakukan kerjasama dengan instansi terkait yaitu BPBD. Peluang yang ada harus dimanfaatkan sebaik mungkin sehingga dapat meningkatkan keefektivitasan pelaksanaan Operasi $S A R$. Sedangkan ancamannya adalah cuaca dan keadaan 
lokasi yang tidak mendukung pelaksanaan Operasi SAR dan permintaan dari keluarga korban yang ingin keluarganya cepat ditemukan namun Kantor Pencarian dan Pertolongan Padang harus bekerja sesuai dengan SOP. Untuk mengatasi kendala-kendala yang dihadapi, Kantor Pencarian dan pertolongan Padang bekerjasama dengan instansi terkait yang memiliki potensi dalam melakukan pencarian dan pertolongan dalam hal ini yaitu Badan Penanggulangan Bencana Daerah untuk menutupi kekurangan akan sarana dan prasarana.

\section{Daftar Pustaka}

Alhadi, Z. (2014). Kesiapan Jalur Dan Lokasi Evakuasi Publik Menghadapi Resiko Bencana Gempa Dan Tsunami Di Kota Padang (Studi Manajemen Bencana). Humanus, 13(1): $35-44$.

Hadi, A. (2013). Konsep Analisis SWOT dalam Peningkatan Mutu Lembaga Madrasah. Jurnal Ilmiah Didaktika: Media Ilmiah Pendidikan dan Pengajaran, 14(1): 143-158.

Moleong, Lexy J. (2013). Metodologi Penelitian Kualitatif. Bandung: Remaja Rosdakarya.

Nurhayati, S. (2015). Analisis Stategis Sistem Teknologi Informasi dengan Pendekatan Analisis Swot (Studi Kasus: Divisi IT Rumah Sakit Mata Cicendo Bandung). In Seminar Nasional Informatika (SEMNASIF), 1(5): 149-154.

Peraturan Kepala Badan Nasional Pencarian dan Pertolongan Nomor 16 Tahun 2017 Tentang Organisasi Dan Tatakerja Kantor Pencarian Dan Pertolongan.

Salusu. (2015). Pengambilan Keputusan Stratejik untuk Organisasi Publik dan Organisasi Non Profit. Jakarta: Garuda.

Sutrisno, J. (2016). Strategi Pengembangan Teknologi E-Commerce Dengan Metode SWOT:

Studi Kasus PT. Chingmix Berhan Sejahtera. Telematika MKOM, 3(2), 44-50.

Undang-Undang No. 29 Tahun 2014 Tentang Pencarian dan Pertolongan.

Undang-Undang No.24 Tahun 2007 Tentang Penanggulangan Bencana. 